\title{
Diurnal and Individual Variations in Bile Acids in the Plasma of Normal Dairy Cows
}

\author{
By Signe Videm Abdelkader and Erlk Ropstad
}

Department of Biochemistry and Department of Reproductive Physiology and Pathology, Norwegian College of Veterinary Medicıne, Oslo.

\begin{abstract}
Abdelkader S. V. and E. Ropstad: Diurnal and individual variations in bile acids in the plasma of normal dairy cows. Acta vet. scand. 1989, 30, 221-228. - Blood samples were collected every $2 \mathrm{~h}$ during a $24 \mathrm{~h}$ period from 6 cows of one herd and 10 cows of another herd. In a third herd 9 cows were sampled every $2 \mathrm{~h}$ from 6 a.m. to 8 p.m. Concentrations of total bile acids, acetoacetate, glucose and free fatty acids were determıned in blood plasma.

A marked difference in individual bile acid concentrations and patterns of diurnal variation was found. For most cows the highest bile acid values were observed between 2 and 6 a.m. (overall mean ( \pm SD) at 6 a.m.: $104 \pm 84 \mu \mathrm{mol} / \mathrm{l}$, range: 20-307 $\mu \mathrm{mol} / \mathrm{l})$. Fourteen cous with a bile acid value $>90 \mu \mathrm{mol} / 1$ at $6 \mathrm{a} \mathrm{m}$ ("high BA") were characterized as a group by showing a pronounced decrease in the mean bile acid concentration after morning feeding. In the group of 11 cows with a 6 a.m. bile acid value $<90 \mu \mathrm{mol} / 1$ ("low BA") the tıme of day did not contribute significantly to the bile acid variation.

For the "high BA" group a nearly synchronous variation between the mean values of the 3 feeding dependent parameters (acetoacetate, glucose and free fatty acids) and the mean values of bile acids was found. The withın anımal coefficients of correlation between bile acids and the feeding dependent parameters were significantly higher in the "high BA" group than in the "low BA" group.

No direct connection was found between bile acid levels and the quantity of concentrates fed or the individual milk yield.
\end{abstract}

liver function; plasma acetoacetate; plasma glucose;

plasma free fatty acids.

\section{Introduction}

Determination of serum bile acids has proved to be a useful test of liver function in humans (Carey 1958, Kaplowitz et al. 1973, Skrede et al. 1978) and dogs (Hauge \& Abdelkader 1984). In these species an increased serum bile acid level serves as a sensitive marker of non-specific liver disease. $A n$ wer et al. (1976) found elevated bile acids in calves after $\mathrm{CCl}_{4}$-induced liver damage. Olsson \& Andersson (1986) found that the stage of lactation significantly influenced bile acid levels, with the highest values ob- served in early lactation. Olsson (1986) also made the finding that dairy cows with parturient paresis had significantly lower bile acid levels than healthy cows at partus. To our knowledge, however, the applicability of the bile acid concentration as an indicator of liver function in ruminants has not been thoroughly studied.

The aim of the present study has been to record the variability of bile acids in apparently normal cows. Special attention is given to the possible occurrence of diurnal variations related to the feeding routine. Acetoacetate, 
glucose (Hove \& Blom 1973, Halse 1982) and free fatty acids (Kronfeld 1965) are bovine blood metabolites showing marked diurnal variation closely associated with the ingestion of food. These parameters were measured together with bile acids in order to compare the patterns of variation.

\section{Materials and methods \\ Animals}

Twenty-five dairy cows of the Norwegian Red Cattle were used, the cows belonging to 3 different herds (6 cows in herd A, 10 in herd $B$ and 9 in herd C). The animals were considered normal, not showing objective signs of disease. Two of the cows in herd A were non-lactating, with calving due within 2 weeks, 2 were in early lactation and 2 in mid-lactation. In herds $\mathrm{B}$ and $\mathrm{C}$, all cows were between 2 and 12 weeks post partum. (Averages were 47 and 53 days post partum for herds B and C, respectively). The cows of herd $A$ were fed at 5:30 a.m. and 2 p.m., whereas in herds $B$ and $C$ the fodder was portioned out at 6 a.m. and 2 p.m. In herd A the fodder consisted of grass silage according to appetite and commercially purchased concentrates (Kufór A). The rations of concentrates were adjusted to Norwegian standards (Breirem 1984). In herds $B$ and $C$ the animals participated in feeding experiments where the cows received concentrates in a $2 \times 2$ design, with 2 crude protein (CP) levels and 2 allowances during week 2-12 of lactation. Grass silage was fed ad libitum. The high protein levels exceeded the standard of digestible CP relative to energy. The lower allowances aimed at underfeeding, notably in herd $C$. The estimated energy balances at the day of blood sampling were $1.4 \pm 1.7$ ( \pm SD) fattening feed units (FFU) and -3.8 \pm 1.8 ( \pm SD) FFU for herd B and C, respectively.

\section{Blood sampling}

Blood was sampled during the indoor season (Nov./Dec.). In the case of herds A and B, samples were collected at two-hourly intervals over a period of $24 \mathrm{~h}$. For herd C, sampling was performed at two-hourly intervals from 6 a.m. to 8 p.m. Heparinized vacutainers were used. The plasma from freshly drawn blood was frozen in liquid nitrogen. When all samples from the herd had been obtained, plasma was transferred to $-80^{\circ} \mathrm{C}$ and stored at this temperature until analysis.

\section{Determination of bile acids $(B A)$}

Determination of plasma BA was carried out with a centrifugal analyser (Gemsaec fast Analyzer from Electronucleonics, Inc.). Total plasma BA were quantified by an enzymatic technique involving $3 \alpha$-hydroxysteroid-dehydrogenase ( $3 \alpha-H S D)$ and diaphorase (Mashige et al. 1981). In a serum/ plasma sample $3 \alpha$-HSD specifically oxidizes all hydroxy BA and their corresponding taurine and glycine conjugates. The method may be applied to bovine plasma as BA with a free $\mathrm{OH}$-group in position $3 \alpha$ and their glyco- and tauroconjugates contribute to more than $95 \%$ of the total BA in bovine blood (Gürtler 1980). In the coupled enzyme reaction $3 \alpha-H S D$ initially oxidizes hydroxy $\mathrm{BA}$ to $3 \alpha$-ketosteroids in the presence of NAD. The NADH formed enables diaphorase to convert nitroblue tetrazolium into coloured formazan. The formazan produzed may be measured spectrophotometrically at $540 \mathrm{~nm}$. Necessary reagents were provided in the commercial kit Enzabile (from Nycomed Pharma, Oslo). All bovine plasma samples were diluted 1:3 before analysis. 
Free fatty acids $(F F A)$, acetoacetate (ACAC) and glucose (GLUC) determination

FFA were assayed by the acyl CoA synthetase - acyl CoA oxidase method (Reagents from Wako Chemicals, W. Germany). Plasma ACAC and GLUC were estimated by the methods described by Blom \& Halse (1975).

\section{Statıstical analysıs}

Statistical analysis was performed by programmes of $S A S$ (1982) (The GLM procedure). The levels of BA were evaluated by linear models which accounted for the effect of the animal factor (cow) and the effect of sampling time.

The variance contribution was calculated for each independent variable from its sum of squares (SS) type III divided by total SS; i.e. (SS III/SS total) $\times 100$ by the $S A S$ (1982) programme (PROC GLM).

The analyses were performed separately for each herd. Alternatively, the animals were grouped according to their BA levels at 6 a.m. A discriminatory level of $90 \mu \mathrm{mol} / 1$ plasma was chosen to distinguish between animals with "high" and "low" BA levels. Testing for significance of differences between coefficients of correlation was performed according to Snedecor (1959).

\section{Results}

For most cows the highest BA values were observed in the early morning between 2 and 6 a.m. The BA concentrations at 6 a.m. averaged $104 \mu \mathrm{mol} / \mathrm{l} \pm 84( \pm \mathrm{SD})$, ranging from 20 to $307 \mu \mathrm{mol} / \mathrm{l}$. The lowest and the highest value were found within the same herd (B).

Twenty of the cows showed decreasing BA values after morning feeding. In cows with a 6 a.m. BA value above approx. $90 \mu \mathrm{mol} / \mathrm{l}$ the decrease was very distinct and rapid (mean values $\pm \mathrm{SE}$ given in Fig. 2). In 1 cow (herd B) the BA value decreased from $270 \mu \mathrm{mol} / \mathrm{l}$ at 6 a.m. to $130 \mu \mathrm{mol} / 1$ at 8 a.m. Only 3 of the 20 cows with declining BA values after morning feeding had values below $50 \mu \mathrm{mol} / \mathrm{l}$ at 6 a.m. In contrast, the remaining 5 cows showed increasing plasma BA levels after feeding. Their BA values at 6 a.m. were conspicuously low, ranging from $20-48 \mu \mathrm{mol} / 1$.

In most of the cows decreasing $\mathrm{BA}$ values were also seen after feeding at 2 p.m. In the late afternoon, at $6 \mathrm{p}$. m., the individual values appeared to be the least diverging (overall mean $\pm \mathrm{SD}: 53 \pm 35 \mu \mathrm{mol} / \mathrm{l}$ ).

In Fig. 1 average BA/time curves for the respective herds are presented. The large variation of plasma BA within the herds is indicated by standard errors. A marked difference between herds was seen, the mean BA

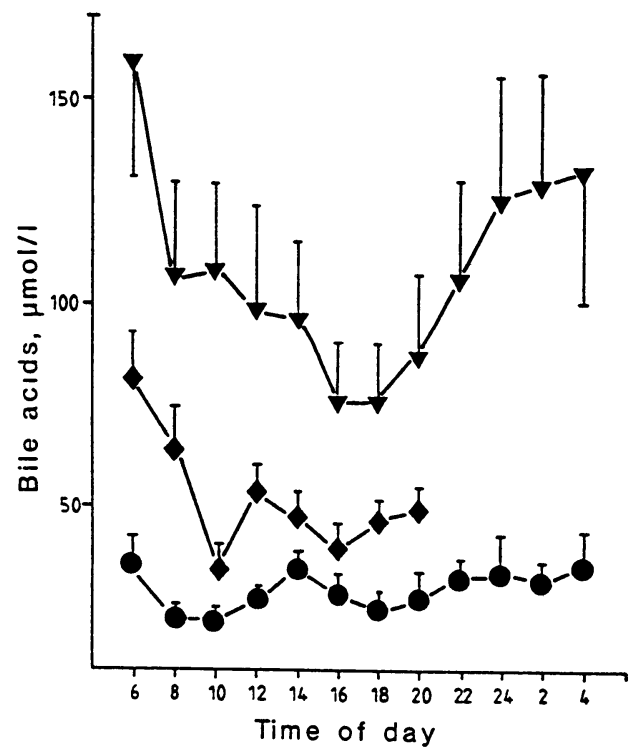

Figure 1. Mean levels of plasma bile acids related to sampling time in Herd A $(\bullet-6$ cows), Herd B (, 10 cows) and herd $C$ $(\diamond, \longrightarrow$ cows). Vertical bars represent standard errors. 
Table 1. Contribution to the variance of bile acids from the anımal factor (Cow) and the time of day (Time). Cows in Herd A and Herd B were blood sampled every second hour for 24 h. In Herd $\mathrm{C}$ blood sampling was performed every second hour between 6 a.m. and 8 a.m. The analysis was first performed separately for each herd. Thereafter all samples collected between 6 a.m. and 8 p.m. were grouped according to the bile acid levels at 6 a.m. A discriminatory level of 90 $\mu \mathrm{mol} / \mathrm{l}$ was chosen to distinguish between animals with "high" and "low" bile acid (BA) levels. Finally, all samples collected between 6 a.m. and 8 p.m. were grouped together.

\begin{tabular}{|c|c|c|c|c|}
\hline \multirow{3}{*}{$\begin{array}{l}\text { Anımal } \\
\text { group }\end{array}$} & \multirow{3}{*}{$\begin{array}{l}\text { Number of } \\
\text { anımals }\end{array}$} & \multicolumn{3}{|c|}{ Percent of total sum of squares 1 ) } \\
\hline & & \multicolumn{2}{|c|}{ Partial effects2) } & \multirow[t]{2}{*}{ Model } \\
\hline & & Cow & Time & \\
\hline Herd A & 6 & $26.8^{\mathrm{c}}$ & $14.1^{\text {ns }}$ & $40.9^{c}$ \\
\hline Herd B & 10 & $71.9^{c}$ & $10.2^{\mathrm{c}}$ & $82.1^{\mathrm{c}}$ \\
\hline Herd C & 9 & $5.3^{\mathrm{ns}}$ & $32.3^{\mathrm{c}}$ & $37.6^{\mathrm{b}}$ \\
\hline High BA & 14 & $60.7^{\mathrm{c}}$ & $19.4^{\mathrm{c}}$ & $80.9^{c}$ \\
\hline Low BA & 11 & $37.6^{\mathrm{c}}$ & $5.4^{\mathrm{ns}}$ & $43.0^{c}$ \\
\hline All anımals & 25 & $72.1^{\mathrm{c}}$ & $7.0^{\mathrm{c}}$ & $79.1^{\mathrm{c}}$ \\
\hline \multicolumn{5}{|c|}{$\begin{array}{l}\text { 1) Level of significance: } b=p<0.01, c=p<0.001 \\
\text { ns }=\text { not significant. }\end{array}$} \\
\hline \multicolumn{5}{|c|}{$\begin{array}{l}\text { 2) (Variable SS type III/total SS) } \times 100 \text {; Proc GLM by } S A S \\
(1982) \text {. }\end{array}$} \\
\hline
\end{tabular}

values of herd $B$ on a level 3 to 5 times higher than those of herd $A$, and with herd $\mathrm{C}$ on a level in between.

According to Table 1 the time of day contributed significantly to the $\mathrm{BA}$ variation in herd $\mathrm{B}$ and $\mathrm{C}$. The variance contributions were $10.2 \%(\mathrm{p}<0.001)$ and $32.3 \%(\mathrm{p}<$ 0.001 ), respectively. The animal factor contributed significantly to the variation of BA in herds $\mathrm{A}$ and $\mathrm{B}$, but not in herd $\mathrm{C}$. In herd $B$ the animal factor accounted for as much as $71.9 \%(p<0.001)$ of the total variation. The variation of BA in the "high BA" group (cows with 6 a.m. BA values $>90$ $\mu \mathrm{mol} / \mathrm{l})$ was significantly influenced by the time of day (Time, Table 1). The variance contribution was $19.4 \%(\mathrm{p}<0.001)$ com- pared to $5.4 \%$ (not significant) in the "low BA" group (cows with 6 a.m. BA values < $90 \mu \mathrm{mol} / \mathrm{l})$.

As illustrated in Table 2, BA showed significant within animal coefficients of correlation with FFA $(r=0.43, p<0.001)$, ACAC $(r=-0.45, p<0.001)$ and GLUC ( $r$ $=0.39, \mathrm{p}<0.001)$. These correlations were reflected in an obvious synchronous variation of mean BA values with the mentioned parameters during the day.

In Fig. 2 the mean values of FFA showed a very distinct diurnal variation both in the "high BA" group and in the "low BA" group. This was in contrast to mean values of BA where only the "high BA" group showed a significant diurnal variation $(\mathrm{p}<$ 
Table 2. Matrix of withın anımal coefficients of correlation between plasma constituents. Samples from 25 cows of 3 different herds were collected every second hour from 6 a.m. to 8 p.m.

\begin{tabular}{lrrrr}
\hline & \multicolumn{4}{c}{ Within animal coefficients of correlation2) } \\
\cline { 2 - 5 } Parameters1) & BA & FFA & ACAC & GLUC \\
\hline BA & 1.00 & & & \\
FFA & $0.43^{\mathrm{c}}$ & 1.00 & & \\
ACAC & $-0.45^{\mathrm{c}}$ & $-0.41^{\mathrm{c}}$ & 1.00 & \\
GLUC & $0.39^{\mathrm{c}}$ & $0.46^{\mathrm{c}}$ & $-0.74^{\mathrm{c}}$ & 1.00 \\
\hline
\end{tabular}

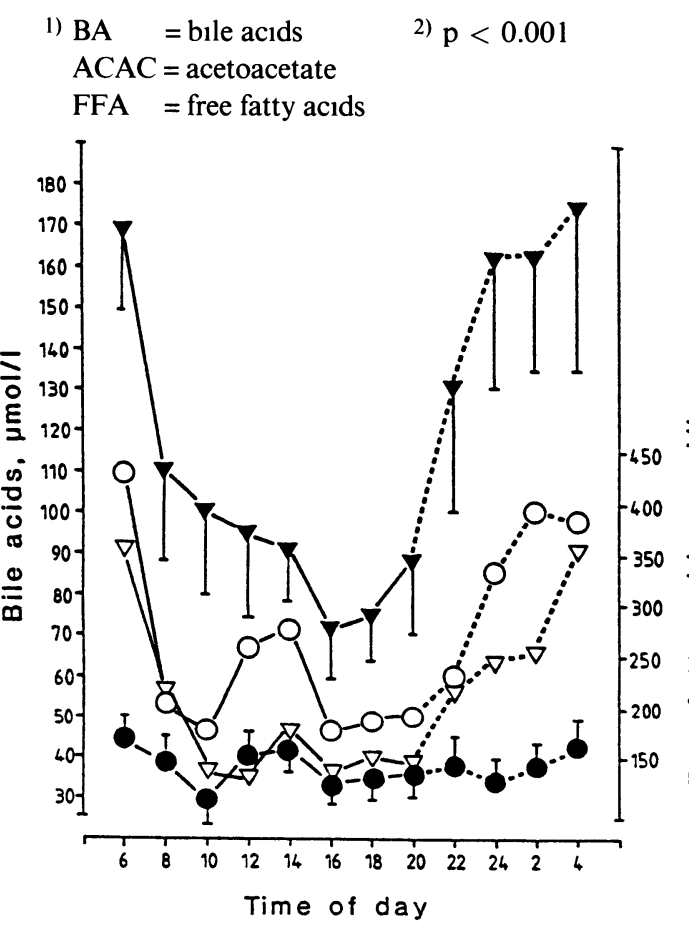

Figure 2. Mean levels of plasma bile acids in 14 cows with "high" $(\boldsymbol{\nabla}-\mathbf{\nabla})$ and 11 cows with "low" (—) bile acid levels. A discriminatory level of $90 \mu \mathrm{mol} / 1$ was used to distinguish between anımals with high and low levels. For comparison, the corresponding mean values of free fatty acids in cows with "high" $(\nabla-\nabla)$ and "low" (Oـ 16 cows were blood sampled between 22 p. m. and 4 a. $\mathrm{m}$. This is marked by dotted lines (-- - -). Vertical bars represent standard errors.
0.001). Similarly, the withın animal coefficients of correlation between BA and the metabolic parameters were significantly higher in the "high BA" group than in the "low BA" group. The coefficients were $r=0.64, p$ $<0.001$ (BA/FFA), $\mathrm{r}=-0.53, \mathrm{p}<0.001$ (BA/ACAC) and $\mathrm{r}=0.51, \mathrm{p}<0.001$ (BA/GLUC) in the "high BA" group as compared to $\mathrm{r}=0.24, \mathrm{p}<0.05$ (BA/FFA), $\mathrm{r}$ $=-0.21, p<0.05(\mathrm{BA} / \mathrm{ACAC})$ and $\mathrm{r}=0.13$, not significant (BA/GLUC) in the "low BA" group. The differences observed were all significant at $\mathrm{p}<0.02$.

No significant interrelations were observed between BA levels and milk yield or quantity of concentrates fed.

\section{Discussion}

The cows in our survey demonstrated a rather non-uniform variation of plasma BA. Even within the same herd a marked difference in individual BA concentrations and pattern of diurnal variation existed.

When the cows were grouped according to their 6 a.m. BA value, the picture became less disorderly. Two "types" of cows appeard: Individuals of the "high BA" group (BA $>90 \mu \mathrm{mol} / \mathrm{l}$ ) showed pronounced diurnal variation with a strong decrease in the plasma BA concentration after morning feeding. The "low BA" group was characterized by smaller fluctuations and a more random variation.

The pronounced diurnal variation of plasma BA found in many of the cows is in contrast to the condition in healthy humans and dogs. Except for a 3-4 fold postprandial rise of about $2 \mathrm{~h}$ duration in the latter species, their plasma BA concentration rests at a low and steady level throughout the day (Fausa 1976, Hauge \& Abdelkader 1984).

In ruminants as in monogastric animals, BA are subject to enterohepatic circulation. Any change in the plasma BA concentration re- 
flects an imbalance between the rate of BA absorption to blood from the intestines and the rate of hepatic reabsorption from the circulation. It is likely that mechanısms determining the plasma BA level are influenced by hormonal and nervous stimuli in connection to feed intake and digestion. Consıdering the distinctive features of feeding and digestion in the ruminant, it is perhaps not surprising that the picture of plasma BA in the cow appears to diverge from that seen in monogastric species.

Vagus nerve activity which is promoted by feeding, enhances the synthesis of BA in the liver. Also conditioned reflexes may increase BA synthesis and secretion (Gürtler 1980). Taking account of the observed decrease in plasma BA concentration after feeding, it seems likely that the uptake of fodder or even the expectation of food, can influence the BA level of peripheral blood. This could imply that the vagus nerve is involved in a feeding-induced lowering of the blood BA concentration.

Analysis of the BA variance showed a moderate connection between the time of day and the plasma BA levels. The animal factor generally contributed more to the total variance (Table 1). Herd $C$ represented an exception, however, the time contributing to almost $1 / 3$ of the variance and the animal factor being non-significant. The relatively narrow range of 6 a.m. BA values combined with a tendency to parallel variation within this herd, could be responsible for this finding.

In search of individual factors influencing the BA variance, record was taken of milk yield and quantity of concentrates fed. A comparison with plasma $\mathrm{BA}$ revealed no connection between this parameter and milk yield or feeding intensity. Similar results were achieved for another group comprising 27 dairy cows (unpublished results). In spite of non-significant correlation between BA and milk yield, one common feature of the 8 non-lactating cows in this group were their exceptionally low 6 a.m. BA values. Also for the 2 non-lactatıng cows of herd A low BA values were observed.

In another experiment 3 cows, ordınarıly fed according to Norwegian standards (Breirem 1984), were given a double ration of concentrates at 6 a.m. on day 1 and no concentrates at all on day 3 (unpublished material). During the experimental period blood was sampled every hour from 5 a.m. to 3 p.m. and plasma BA determined. No significant changes in BA levels occurred from day 1 to day 3. This was true for 2 cows showing low BA and little diurnal variation, as well as for the cow with a high 6 a.m. BA level and pronounced variation.

It was found by Ropstad (to be published) that dairy cows generally have low BA values before calving. After calving the 6 a.m. BA values increase gradually to reach maximum values 6-7 weeks post partum. Thereafter the BA level slowly decreases and eventually reaches the lowest values some weeks before calving. This is in accordance with the findings of Olsson \& Andersson (1986).

The difference in plasma BA values between herds $\mathrm{B}$ and $\mathrm{C}$ can hardly be explained on the basis of time after calving, as this factor is practically the same for both herds. The most evident distinction is the underfeeding of the herd $\mathrm{C}$ cows. In spite of the lack of correlation between BA level and individual feeding intensity in our material, the general feed strength might possibly influence the BA pool over time and thereby the BA level of blood.

To test the hypothesis that digestion and absorption are important inducers of BA diurnal variation, plasma concentrations of ACAC, GLUC and FFA were compared to the corresponding BA concentrations. A 
high degree of synchrony occurred in the group of cows with BA values above 90 $\mu \mathrm{mol} / \mathrm{l}$. In the "low BA" group, however, only low coefficients of correlation could be demonstrated between $\mathrm{BA}$ and the 3 feeding-dependent parameters. These results indicate that there is no direct relationship between BA and the 3 blood metabolites. The synchronous variation observed between BA on one hand and ACAC, GLUC and FFA on the other, may be a coincidence of physiological events.

Due to a marked variation of plasma BA levels in normal dairy cows and little knowledge of the sources of variation, it seems difficult to define reference ranges for this parameter. The impression so far, is that the plasma BA concentration is not applicable as an indicator of liver function in cattle in the same way as serum BA in humans and dogs.

\section{References}

Anwer MS, Engelking LR, Gronwall R, Klentz $R D$ Plasma bile acid elevation following $\mathrm{CCl}$ induced liver damage in dogs, sheep, calves and ponies. Res. Vet. Sci. 1976, 20, 127-130.

Blom AK, Halse $K$ Corticosteroids in nocturnal blood plasma of cows in the field related to stage of lactation and plasma acetoacetate. Acta Endocr. (Kbh.) 1975, 78, 306-315.

Breirem $K$ Fôrnormer. (Feeding standards). In K. K. Heje Lommehåndbok (ed. K. Singsaas). P. F. Stensballes Forlag, Oslo, 1984, pp. 188200.

Carey $J B$ The serum trihydroxy-dihydroxy bile acid ratio in liver and biliary tract disease. J. Clin. Invest. 1958, 37, 1494-1503.

Fausa $O \cdot$ Serum bile acid concentration after a test meal. Scand. J. Gastroent. 1976, 11, 229232.

Guirtler $H \cdot$ Die Physiologie der Verdauung und Absorption. In Lehrbuch der Physiologie der Haustiere (ed. E. Kolb). (The Physiology of
Digestion and Absorption. In Textbook of Domestıc Anımal Physıology). Veb Gustav Fisher Verlag, Jena 1980, p. 177-339.

Halse $K$ Ketosis research in Norway. The Norwegian College of Veterinary Medicine, Publications 1981 (ISSN 0078-6721) 1982, 5-13.

Hauge JG, Abdelkader SV Serum bile acids as an indidator of liver disease in dogs. Acta vet. scand. 1984, 25, 495-503.

Hove $K$, Blom $A K$ Plasma insulin and growth hormone in darry cows; diurnal vanation and relation to food intake and plasma sugar and acetoacetate levels. Acta Endocr. (Kbh.) 1973, 73, 289-303.

Kaplowitz N, Kok E, Javitt NB Postprandial serum bile acid for the detection of hepatobiliary disease. J. Amer. med. Assoc. 1973, 225, 292-293.

Kronfeld DS Plasma non-esterified fatty acid concentrations in the dairy cow: Responses to nutritional and hormonal stımuli, and significance in ketosis. Vet. Rec. 1965, 77, 30-35.

Mashige F, Tanaka N, Makı A, Kameı S, Yamanaka $M$ Direct spectrophotometry of total bile acids in serum. Clin. Chem. 1981, 27, 1352-1356.

Olsson $T$ Serum bile acıds in hypocalcaemic dairy cows Proc VI Int Conf Prod. Dis Farm Anım, Belfast 1986, p. 20-23

Olsson T, Andersson L Serum bile acid variations in healthy dairy cows. Israel J. vet. Med. 1986, 42, 296-299.

Skrede S, Solberg HE, Blomhof JP, Gjone E. Bile acids measured in serum during fasting as a test for liver disease. Clin. Chem. 1978, 24, 1095-1099.

Snedecor $G W$ Statistical Methods. Iowa State college Press, 1959, p. 175-179.

Statistical Analysis System (SAS) SAS User's Guide: Statistics, SAS Institute Inc., Cary, N. C. 1982.

\section{Sammendrag}

Dognvariasjon og individuelle variasjoner av gallesyrer i plasma fra normale melkekyr. I løpet av 24 timer ble det tatt blodprøver hver 2. time fra 6 melkekyr 1 én besetning og 10 melkekyr 
1 en annen besetning. I en tredje besetning med 9 dyr ble det tatt blodprøver hver 2. time mellom $\mathrm{kl}$. 6 og 20. Plasmakonsentrasjonen av gallesyrer, acetoacetat, glukose og frie fettsyrer ble bestemt. Det kunne påvises store forskjeller i individuelle gallesyreverdier og 1 døgnvariasjonsmønstre. De fleste kyr hadde høyeste gallesyrenıvå mellom kl. 2 og 6 om morgenen (middelverdı ( \pm SD) kl. 6: $104 \pm$ $84 \mu \mathrm{mol} / \mathrm{l}$, sprednıng: $20-307 \mu \mathrm{mol} / \mathrm{l})$. Fjorten $\mathrm{kyr}$ med gallesyreverdi $>90 \mu \mathrm{mol} / 1 \mathrm{kl} .6$ ("hıgh BA") ble som gruppe karakterisert ved å fremvise en sterk nedgang 1 gjennomsnittlig gallesyrekonsentrasjon etter fôrıng om morgenen. For de resterende $11 \mathrm{kyr}$ med en gallesyreverd $\mathrm{kl} .6<90$ $\mu \mathrm{mol} / \mathrm{l}$ ("low BA") ga ıkke prøvetakıngstidspunktet noe signifikant bidrag tıl variasjonen 1 gallesyreverdier.

For gruppen "hıgh BA" var det nesten synkron varıasjon mellom gjennomsnittsnivåene for gallesyrer og gjennomsnittsnivåene for de 3 fôrıngsavhengige parametrene acetoacetat, glucose og frie fettsyrer. Korrelasjonen innen dyr mellom de 3 sistnevnte parametrene og gallesyrer var sıgnıfikant høyere 1 gruppen "high BA" enn 1 gruppen "low BA".

Det ble ikke funnet noen direkte sammenheng mellom gallesyrenıvå og kraftfôrinntak eller melkeytelse.

(Recelved Aprll 17, 1988, accepted August 18, 1988)

Reprints may be requested from: Signe Vıdem Abdelkader, Norwegıan College of Veterınary Medıcıne, P. O. Box 8146 Dep., N-0033 Oslo 1, Norway. 